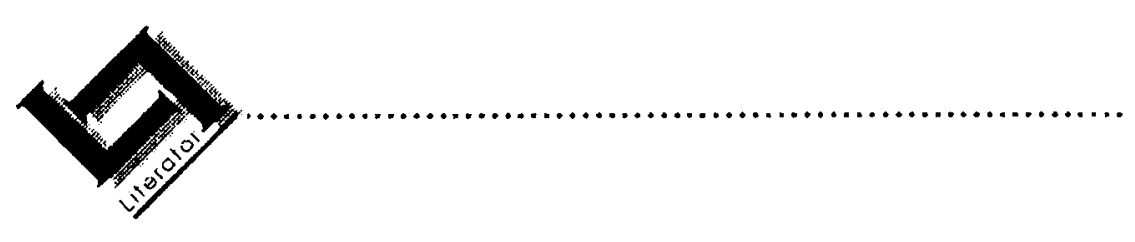

\title{
Imagining Afrikaners musically: Reflections on the "African music" of Stefans Grové
}

\author{
Stephanus J, van Z. Muller \\ Balliol College \\ Oxford \\ E-mail: sjvzmuller@msn.com \\ Abstract
}

Imagining Afrikaners musically: Reflections on the "African music" of Stefans Grové

For nearly two decades Stefans Grove has been composing music that absorbs the cultural "Other" of Africa in a manner that defies an easy classification of "indigenous" principles and "exotic" appropriation. His own conception of himself as an African who composes African music challenges the inhibition of "white" Afrikaner culture and revivifies Afrikaner culture as African culture. In so doing, Grove is consciously subverting the myth of a united Africa over against a monolithic "West" - and with it the legitimacy of an autochthonous echt African culture previously excluded by "whites" and Afrikaners. This article takes a closer look at the strategies and techniques involved in this fin de siècle musical imaginings of Afrikaner identity. A reading of Grove's Sonate op Afrika-motiewe provides the basis for the speculative reflections that follow.

Ek ken die Afrika-son wat warm op my musiek skyn. Ek ken die nagsugte en die fluistering van die 'vuurmense' oor eeue-oue dinge in die skadu's van vervloë mane. Ek voel die geluid van Afrika in hart en wese. Ek is 'n Afrika-mens wat Afrika-musiek skryf.

II know the African sun that shines warmly on my music. I know the sighs of the night and the whispers of the fire people about ancient things in the shadows of passing moons. I feel the sound of Africa in heart and soul. I am an African person writing African musicl Stefans Grové, 1997a. 


\section{Afrika-mens/Africa(n) person}

Afrika-mens. Africa(n) person. Not African, but Africa(n) person. Somehow the English translation of the Afrikaans concept is inadequate, for what the speaker refers to is more a state of being than a description or classification of race, nationality or even geographical origin. It is African existence as a lived symbolic form, as opposed to blander "namings" such as "South African" or even the irremediably pejorative "Afrikaner". An Africa(n) person composing Africa. How does this music sound and where does it come from? Europe, where Stefans Grové's ancestors hail from, the United States, where he spent 18 years teaching and composing, or (South) Africa, where he has only ever lived in white suburbia? None of these, Grové seems to say when he writes of his seminal Sonate op Afrika-motiewe, a work composed for violin and piano in 1984:

This sonata ... is the first work I composed after my stylistic Damascus Road experience. It can be seen as a bridge between my Eurocentric and my Afrocentric styles, as the first two sections represent my leave taking of my previous style, whilst the last three are my first homage to the way I am bound to Africa [Afrikagebondenheid].

The last three parts are based on an indigenous song that I heard one day, under the midday sun, as sung by a pick-ax wielding black man. The song first appears in its totality at the beginning of Finale II. In parts 3 and 4 fragments thereof try finding their way, and the strongest of the motives is worked out to such an extent that the appearance of the 'mother theme' from which it is taken, forms a logical conclusion (Grové, 1997b).

\section{Where does this music come from?}

The question of where this music comes from elicits a surprising response. A stylistic Damascus Road experience suggests that it comes from "above", or "beyond", or "inside", or wherever that place is that is inhabited by metaphysics and/or divine inspiration. It is, however, Jean Cocteau to whom Grové points as the catalyst of his musical catharsis his pronouncement that "the more a poet sings from his family tree, the more authentic his song will be" (Grové, 1997), supposedly triggering the Sonate op Afrika-motiewe and with it Grové's musical "African" series in 1984. We return to Grove's short programme note on the Sonate, and specially mention of the indigenous song. It is worth pausing on the idea of this song (see example 1), that recalls the Primitivism so much in vogue during the previous fin de siècle and the early part of the 20th 
century; a Primitivism very much part of the panoramic modernist gaze enmeshed in the ideologies of empire and colonialism.

Example 1. Grové, Sonate op Afrika-motiewe, Finale 2, violin, bars 7-10.

$$
\text { Meno mosso d. }=138
$$

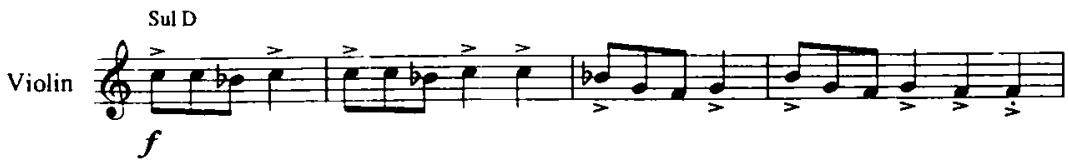

Picasso's Les Demoiselles d'Avignon of 1907, the picture symbolizing the inauguration of Modernism in the arts, provides a fitting analogy to Grové's use of an African melody. Like Grové's five movements, three of Picasso's five female figures display stylized African masks. The figures blunt our perspective, the space of the room creates the feeling that everything is pushed to the surface. Les Demoiselles d'Avignon was the beginning of the end for perspective in painting in favour of simultaneity of exterior and interior, of inner and outer space. A revolutionary idea of space-time, availing itself of the voodoo magic of ancient and primitive ritual, where the conceptual rudimentariness of the African artifact is perhaps more of an energizing authority than an obsession with primitive societies of a distant past. Grové's "song" is a bit like these stylized African masks, sharing their space with the two remaining etiolated European faces: ahistorical, anonymous and devoid of the political potency infusing the song of the African who, under the strain of centuries of repression, breaks into song. But there is more to Grove's project than the trajectory linking his practice with the Primitivists would suggest, and it is to trace the multiple references and overlapping fields of meaning that we now turn to examine the Sonate op Afrika-motiewe, indexing as it does the more ambiguous discourses and phantasms of belonging that refute the idea of cultural homogeneity and that constitute the politics of memory and the search for new identities in post-Apartheid South Africa.

\section{Sonate op Afrika-motiewe}

\section{- Contrast between the first two movements and the rest}

The five parts of the sonata are called Recitativo: Notturno 1, Ditirambo, Intermezzo: Finale 1, Notturno 2, Finale 2. As Grové himself has in- 
dicated, the first two movements fit together conceptually, as do the last three. At first hearing, a significant contrast does indeed become apparent between the first two movements and the rest of the work: in the former the absence of an identifiable melodic, harmonic or rhythmic idea creates a universal law impervious to the accident of time and place. As Christopher Waterman has pointed out, the metaphoric forging of correspondences between musical and social order is often more a matter of expressive qualities (timbre, texture, rhythmic flow) than of abstracted musical structures (in Erlmann, 1996:236-7) and indeed the self-conscious juxtaposition of registral soundscapes in these two movements becomes primarily a description of universal space. Diachronic time absents itself from movements one and two: static passages hypnotize temporal awareness in movement one, fractured melodicism mesmerizes the listener in its almost palpable sensuous sound in movement two. Time and place float out of reach in the fusion of the composer's own deep spirituality and modernity in a dream of unity and wholeness of which the "meaning" is no longer in the world (and therefore not merely global), but truly transcendental and universal. But the claim to this kind of "wholeness" can be traced to a Platonic-Christian metaphysic scope that is essentially anti-terrestrial and where the "truth" can only be asserted in what Wole Soyinka has succinctly described as "an idea of the cosmos that recedes so far, that while it retains something of the grandeur of the infinite, it loses the essence of the tangible and the immediate" (in Soyinka, 1976:3-4). In movements one and two we therefore observe modernism's deceitful conceit: the promise of wholeness exposed as an imagined unity, maintained only by the sheer impossibility of bridging the chasm between the tangible and the imagined.

\section{- Motivic scatterings}

In movements three, four and five, however, this cosmic Manichaeism is shattered by the motivic scatterings of the song breaking forth from the African soil, as it were. Time and space are localized and cosmic totality reasserted by reclaiming that mundane part of it which is the local place. The invented nature of the category "indigenous" in Grové's description of the song he uses, invoking long-defunct Western fixities of place and identity, hardly matters. Though not reducible to a local dialect - "working in Afrikaans", as Breyten Breytenbach contentiously asserts of the painter François Krige (Breytenbach, 1998:117) - Grové's music does posit (like Krige's paintings) the possibility that the "universal" embracing African and Western musics lies not at the level of immanent structures, but at the level of poietic (production) and esthesic (reception) strategies (Nattiez, 1990:76). It is a move that partakes "of the goal of all symbolic practice: the returning of the whole" (Erlmann, 1996:133), becoming no less than the transformative gesture of the global imagination with which 
Grové enters Soyinka's "fourth space" of African metaphysics: "the dark continuum of transition where occurs the inter-transmutation of essenceideal and materiality" (Soyinka, 1976:26).

\section{- Structural relationship in this sonata}

There is another structural relationship at work in the sonata - one that is first hinted at not in the music but in the accompanying rubrics - that suggest that movements one (Notturno 1) and four (Notturno 2) have a special relationship, as do movements three (Finale 1) and five (Finale 2). Finale 1 and Finale 2 exhibit obvious similarities: the motoric momentum, the ever more recognizable African melody, the airy textures, the dance-like rhythm. Finale 2 takes the music up where Finale 1 has left it, providing the postponed ending to the false start of the end promised by Finale 1 (movement three). It is Notturno 2 that creates a fissure in this act of closure. The rubric inevitably turns our thoughts back to movement one, also entitled Notturno. It is not difficult to see or hear the musical relationship between the two movements, a relationship most notably confirmed by a dialogic form and piano chords composed out in elaborate diminutions (see examples $2 \mathrm{a}$ and $2 \mathrm{~b}$ ). But there is also a difference: in Notturno 1 the violin's voice, although distinct, remains anonymous, whereas the emerging violin in Notturno 2 can be recognized as belonging to both Africa (the first notes of its initial appearance, marked in bars 4 and 6 of example $2 b$, are taken from the African song), and to the occidental world of the first nocturne. This latter identity is the result of the repeated major 2nd interval (marked in bars 4 and 6 of example 2b), that follows the "African" notes, and which is taken from the first two notes of the violin in Notturno 1 (marked in bar 2 of example 2a). Though made present by the iconic prominence of the major 2 nd, the latter world is now transformed (transposed): the distinctness of the major 2 nd concatenated into a single sound gesture by a glissando that becomes a feature of its subsequent appearances. The two worlds, (South) Africa and the West, are imagined on a sliding scale transfiguring power from the structured interval of measured difference to the agency of the irreducibly ambiguous physical sound that now fills it.

\section{- Plot/thematic development interrupted}

There is another striking feature of the second nocturne, namely the long periods in which the music seems to lose interest in the "plot" of thematic development. The haunting stasis of the first nocturne becomes a presence so dominating that emptiness itself becomes a feature. It is almost as if one expects visual compensation for the lack of direction, for some sort of choreography to fill the stage of the mind. But whereas music itself seemed hypnotized by the ultimate modernist dream of 
Example 2a. Grové, Sonate op Afrika-motiewe, Notturno 1, violin and piano, bars 1-6.

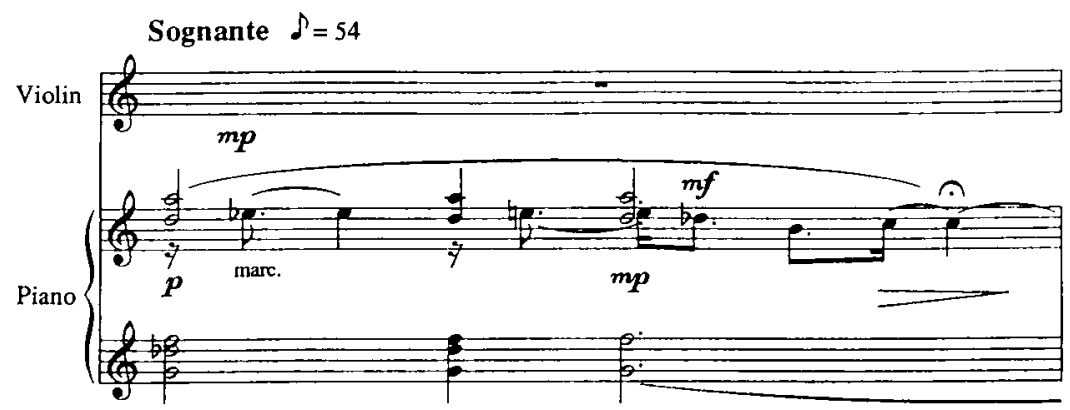

Q80.
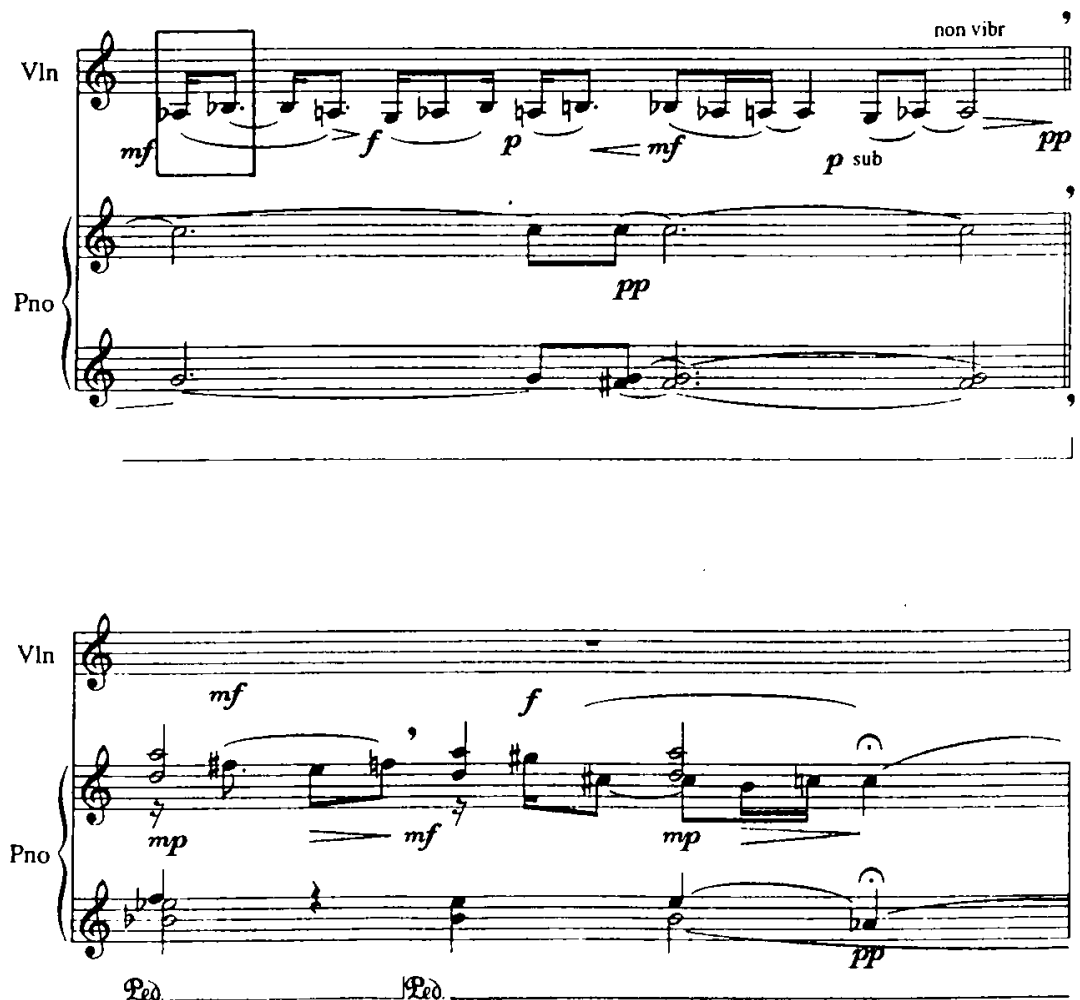

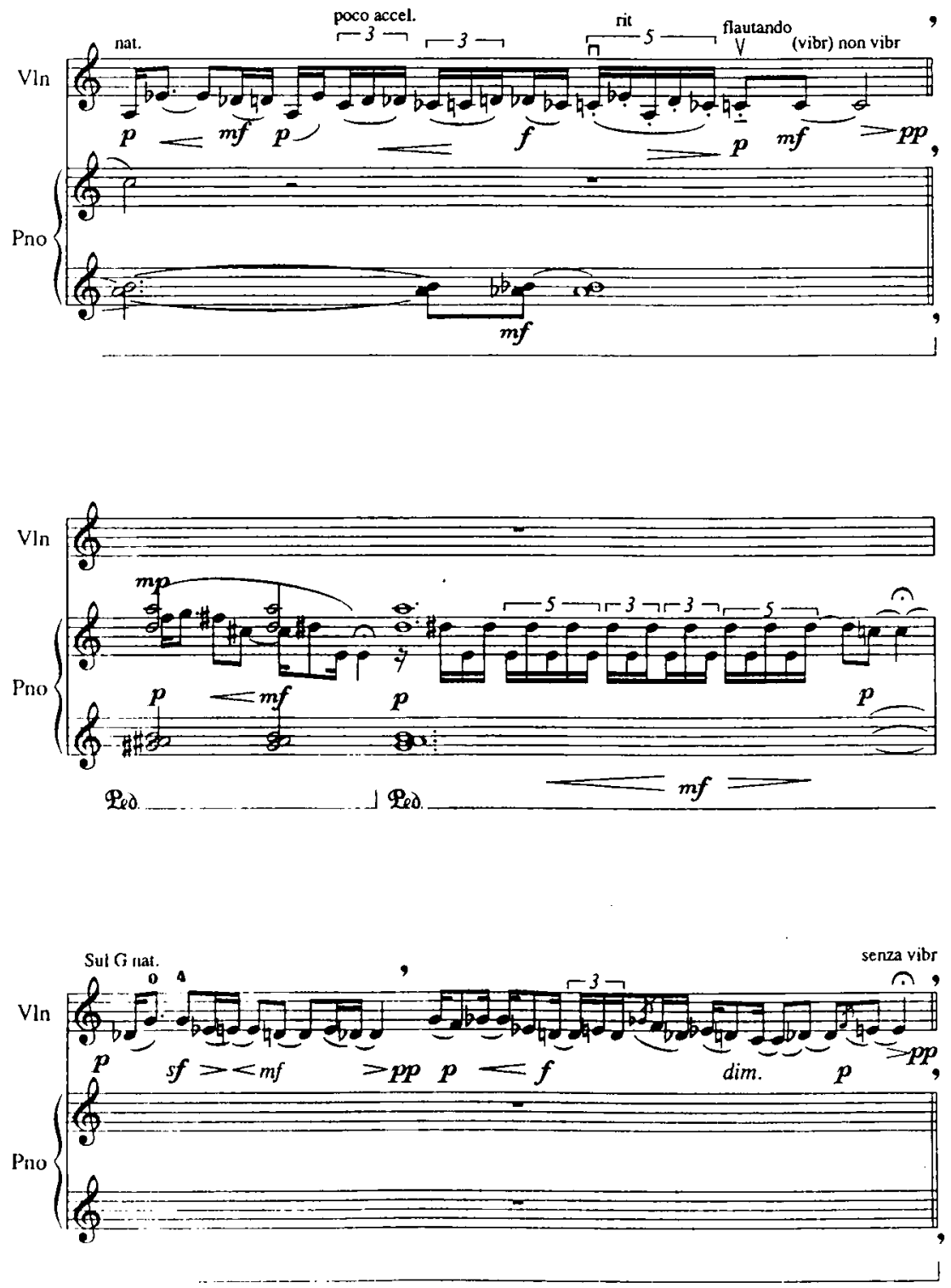
Example 2b. Grové, Sonate op Afrika-motiewe, Notturno 2, violin and piano, bars 1-7.
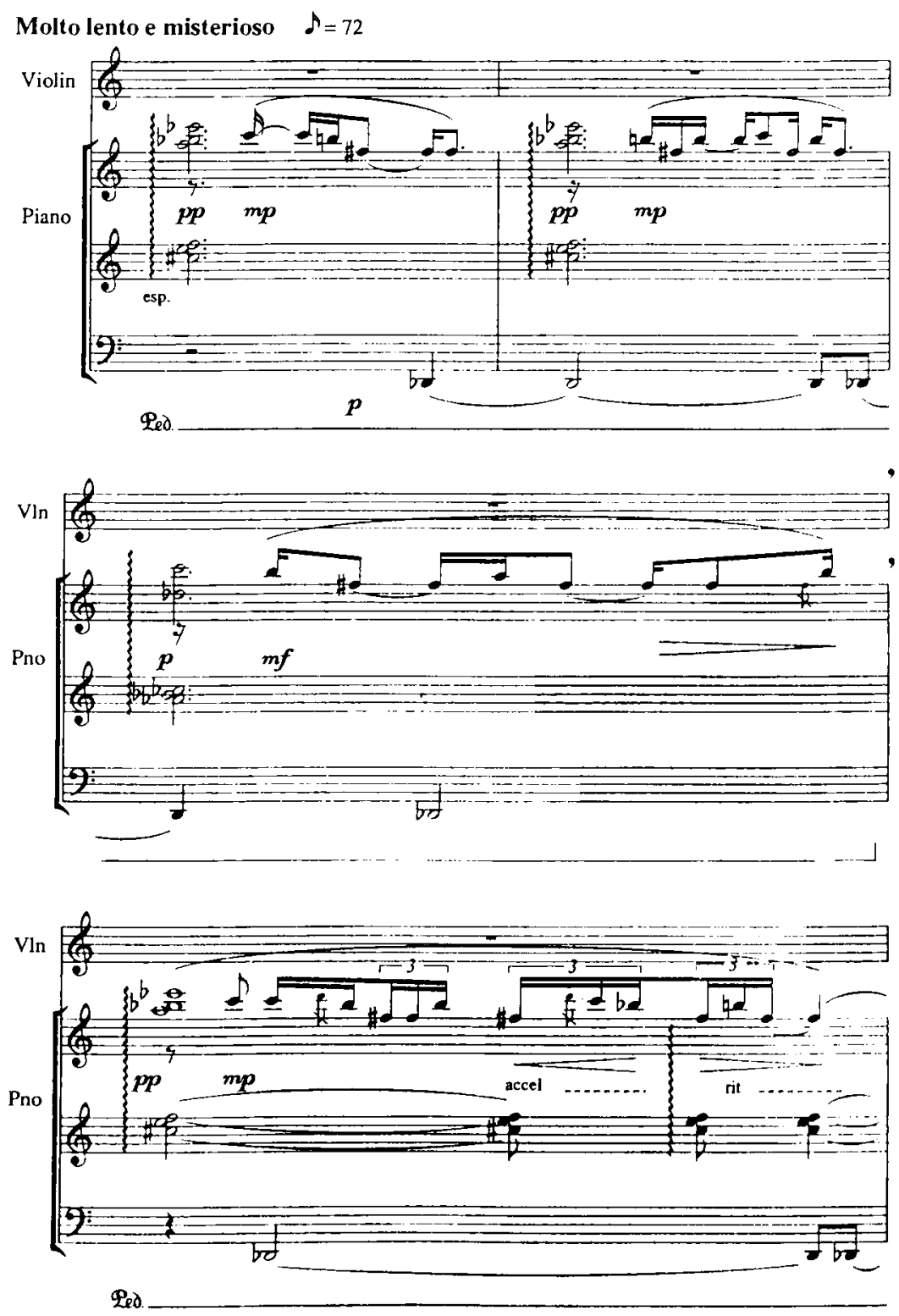

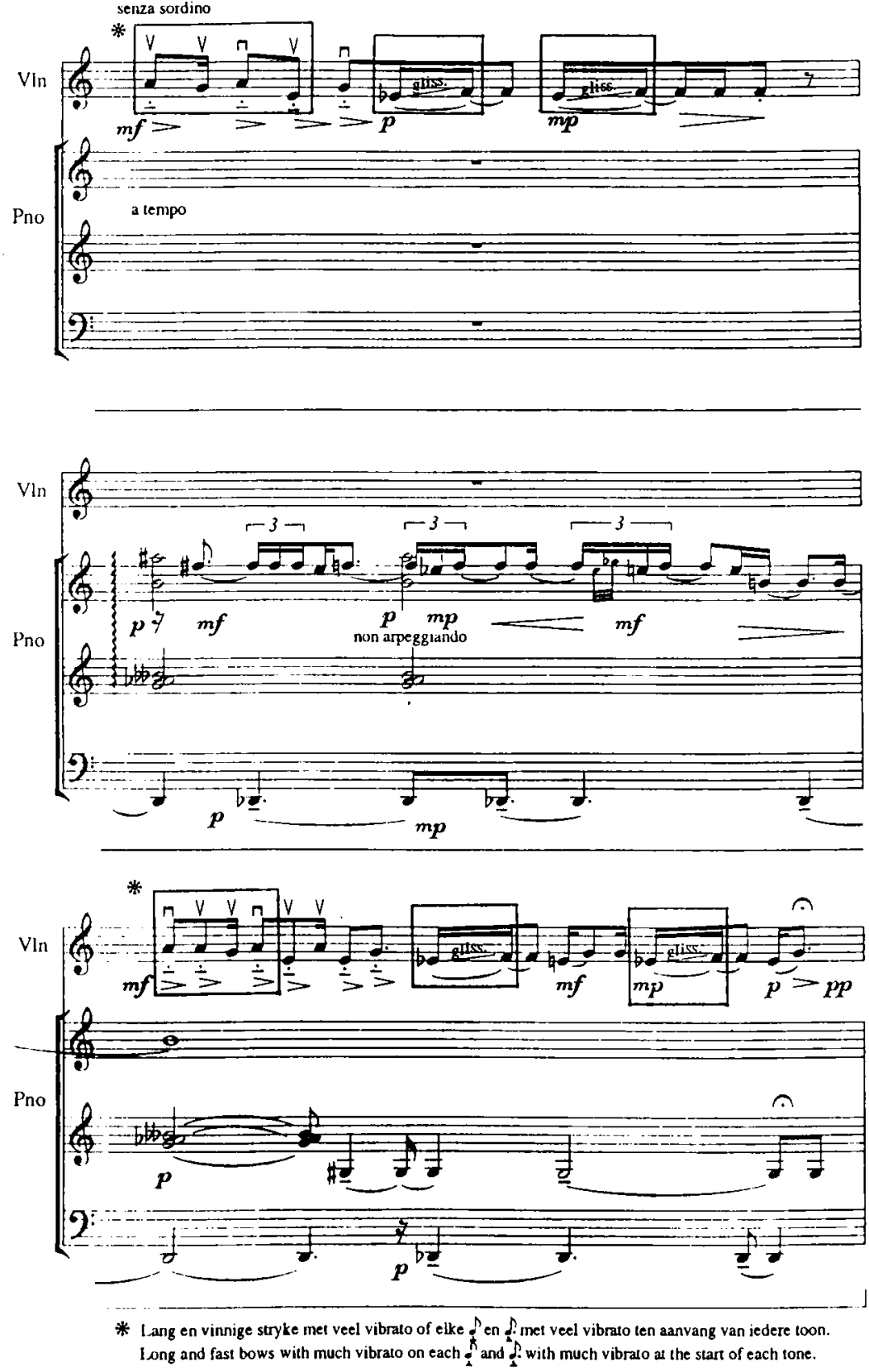
Example 3. Grové, Sonate op Afrika-motiewe, Notturno 2, violin and piano, bars 11-15.
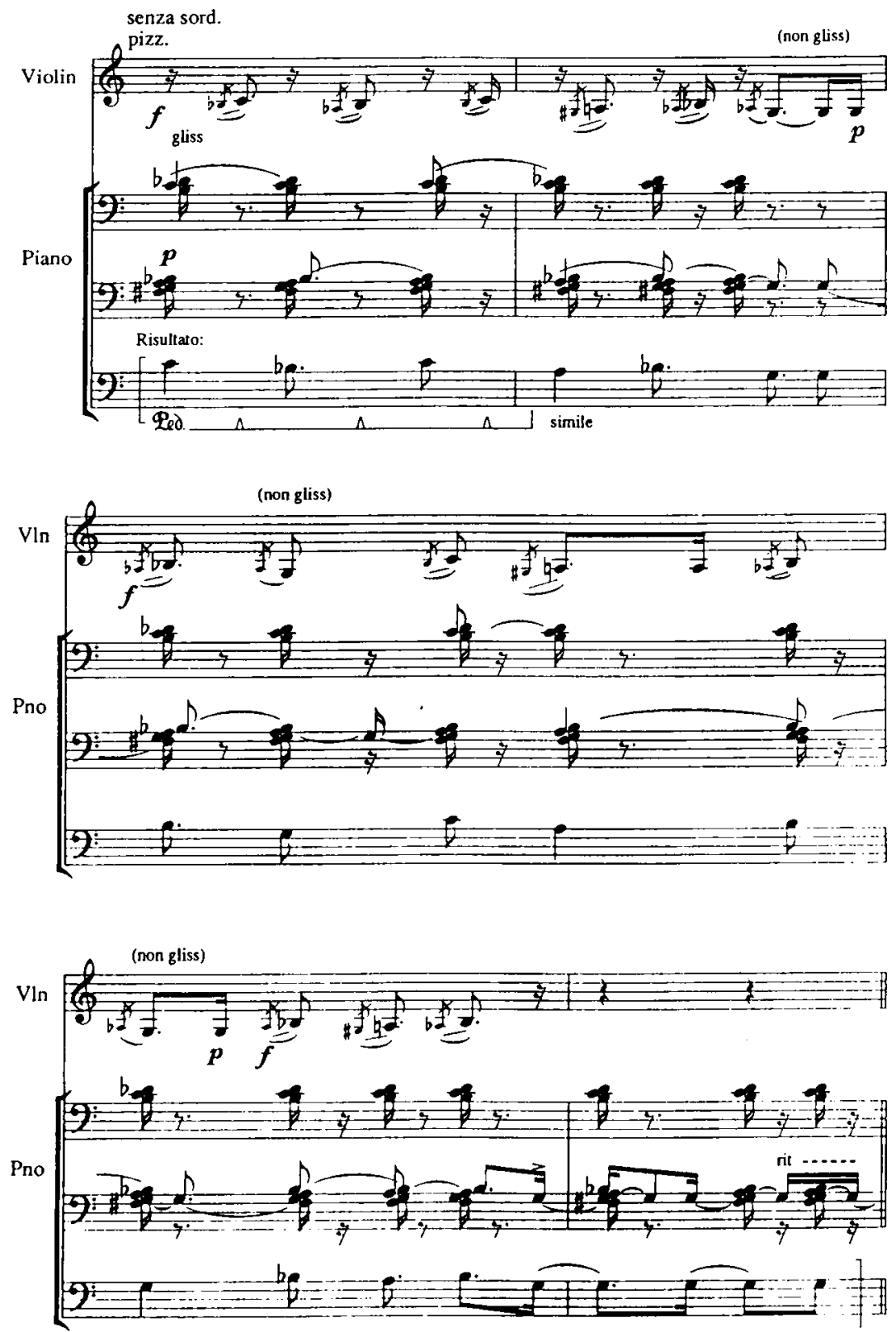
totality in the first nocturne, the music of the second nocturne accompanies the questioning look, losing interest in anything other than its own physical presence. The temporal "enclosures" (see example 3), created by what can perhaps be called "timbre modulations", are significantly enhanced by their occurrences as a calculated interruption of Finale 1 and Finale 2. Grové makes clear here that his art consists in making things heard, not the things he represents, but those he manipulates. To paraphrase Barthes on Cy Twombly, Grové permits the sounds to linger in an absolutely aerated space; and the aeration is not merely a plastic value that forges unity of form, it is a kind of subtle energy that makes it easier to breathe. These spaces are big rooms which the mind seeks to populate (Barthes, 1991:182-83). They invite active participation (and communality) in the delights of sheer physical sensuous soundscapes and spaces which constitute nothing but sound, thus becoming a kind of musical background to a ritual drama, i.e. drama as a cleaning, binding, communal and recreative form (Soyinka, 1976:4).

And yet, despite this almost mystical use of soundmaterial, it is clear that the conception of the work owes more to the Beethovenian reworking of small motivic cells in an exquisitely translucent counterpoint than to a process of exotic collage. A theme is prepared in such a way in order that its appearance at the apotheosis of the work is perceived as "logical". That this material is derived from an African theme is almost incidental, but nevertheless noteworthy in one important respect: Grové uses his technical facility as an art music composer to make the outcome, which he imagines as the transculturated movement, sound "logical". One might add, "natural". The technique used is anything but natural in relation to the aims sought, and we are reminded of Arnold Schoenberg's (1984:167-69) disapproval of what is in fact a Bartókian idea:

... ideas from folk-art [are] treated according to a technique that [was] created for ideas of a more highly developed kind. The difference between these two ways of presenting an idea [is] overlooked, and there may even be an underlying difference between two whole ways of thinking.

What Schoenberg did not think possible is what we are contemplating here: that this perceived discontinuity between materiality and technique can only be resolved in the person of the composer, who experiences both African (sonic) identity movement and the technical means with which he manipulates it as "logical" and "natural" and thus as somehow not only compatible but even the same, or identical. 


\section{- The restoration of music as symbolic fact}

To interrogate Grové's Africanicity (especially as a token of political good faith) is of no use. To quote Roland Barthes writing about Ertés Women, it says nothing more than itself, "being scarcely more loquacious ... than a dictionary which gives the ... definition of a word, and not its poetic future" (Barthes, 1991:114). The characteristic of the signifier is to be a departure; and the signifying point of departure, in Grove's music, is not Africa; it is Authenticity, i.e. a restoration of (art) music as symbolic fact into a living social and cultural content. The music's conceit is that of a microcosm, which, as Wole Soyinka has written with regard to ritual African theatre, "involves a loss of individuation, a self-submergence in universal essence" (in Soyinka, 1976:42). But with Grové the loss of individuation taken aboard by vicariously adopting Africa as "theme" is checked by the vigorous assertion of creative individualism that makes diversity the single most common denominator of the composer's "African series", and while the name of "Africa" is invoked over all this difference, it would be fanciful to say that these compositions evoke "Africa" in any sense. Grové's (possibly disputed) success in denoting "Africa" is not immediately (if ever) apparent in or through his soundscapes, but rather through the concurrent structures of titles, fables, dreams, intertexts, narratives and descriptions. One example is the fable that accompanies the Trio for flute, cello and piano of 1998:

Once in far away times, in a far away, far away land lived an ancient people in a desert-like landscape where the sun shone hot during the day and the stars seemed very bright and near at night. And so, one night, when everyone was asleep and the chieftain of this tribe of soulless people sat alone next to the dying fire, he suddenly saw a bright shooting star. The star became a strange bird which settled in the tree next to the old man, and began to sing a plaintive song of great longing. The chieftain spoke to the bird and asked the reason for its sadness. The bird answered that it was a soul without body, and only visible to the chieftain. It said that the chieftain was a body without a soul - like an animal. If the two of them could be unified they would be wise like the spirits of their ancestors; like the sun, the moon and the wind. And so it happened that body and soul became united. Then suddenly at midnight shooting stars began to rain from heaven and each turned into a bird, a soul bird. And they began to sing their dream songs of yearning to become part of the other tribe members. Towards dawn each of the souls had found a body, and all rose from the ground and flew towards the rising sun to meet with him, and to become wise like him (Grové, 1998).

It is tempting to think of this kind of story as a borrowing from the easy intercourse between the living and the dead that forms such an integral 
part of oral traditions in languages like Zulu, Xhosa and Sotho. But again the searching gaze is frustrated in its quest for its African Other, for this kind of "magic realism" is also rooted in Afrikaans literature from where it is developed by the ghost stories of the Voortrekkers and later the work of Eugène Marais, Louis Leipoldt and C.J. Langenhoven. Grové is in step with what André $P$. Brink has called "the inevitable return to roots which political events and the fin de siècle have prompted in South African writing across the cultural spectrum" (Brink, 1998:26). This constant in Grové's compositions since 1984, namely that we have musical structures existing side-by-side with linguistic ones, also manages to leave much unsaid. In fact, Grové creates two heterogeneous structures that occupy separate if contiguous spaces informing one another, but refusing either to homogenize or mingle. The denoted message of "Africa" is, for now, nothing but Name - open and vague - and therefore encouraging of connotation. How do we relate the analog (which is the Name) to the concurrent musical structure? I have tried to show how, in the case of the Sonate op Afrika-motiewe, this can be done as an act of conscious imagination, but not without the aid of language. Grové knows, and here I am following Barthes closely again, that the Name has an absolute (and sufficient) power of evocation; that if a work is called Afrika Hymnus, for example, we need not look for "Africa" anywhere except, precisely, in the Name. To write Boesmanliedere is to hear Bushmen. Ignore the title (language), and the composition, it would seem, escapes.

In a sense, to compose a work like the recent piano concerto called Raka, is to stage a performance of (Afrikaner) culture: N.P. van Wyk Louw's historical text is not represented but evoked by the Name. In short, what is represented is (Afrikaner) culture itself, or the inter-text, described by Barthes (1991:190) as the circulation of anterior or contemporary texts in the artist's head or hand. But to represent Afrikaner culture, in the context of an adumbrated symbolic Africa, is to restore to it (and art music with it) its local space. Grové's concept of authenticity does not seek to undermine The West, or even the individual as a major Western Idea. His music represents an adaptation of the traditional art music framework rather than a radical break from it. The suggested trajectory linking Grové's project with that of the musique nègre of the early Modernists in Paris is therefore not as fortuitous as his Cocteauderived credo might imply. One recognizes in the work of the Primitivists Grové's commitment to the colonialist idea of the primordial African space, an ahistorical space, if you will, where history can be started afresh, as well as a continuation of what Glenn Watkins (1994:57) has called a "venerable tradition of appropriating the foreign in the service of defining the familiar". This is music that conceives of Africa as a meaning (and identity), not as subject. But, and this is an important difference, 
with Grove the adoption of Africa as analog is both an act of participation in the reconstitution of meaning and social gestus. This music does not metaphorically enact the crossing of two radically opposed worlds, but rather suggests a gesture at interaction between two facets of the same social space.

\section{- The reconstitution of meaning and identity}

This reconstitution of meaning and identity is generally misunderstood by the urgent need of much recent South African musicology to prove agglutinated synthesis as a trope for a "unified South African nation". Illuminating this misunderstanding is a review of a concert dedicated to Grové's works in 1997, in which eminent South African musicologist Mary Röhrich makes the following remark about the Afrikaner choir that performed Grové's Psalm 150 for double choir and percussion on a Southern Sotho text:

Trapped in colour-coded, humourless robes whose designer label surely reads Calvin (without the Klein), the Unisa Ad Libitum Choir shuffled their way self-consciously through their prescribed choreography, faces buried in scores and emotions reduced to mere vocal emissions. One cannot but wonder what a black choir might have done with the music and its celebration (Röhrich, 1997).

This injunction for Afrikaners to become something which they are not is not issued to Grové's music:

Grove has reached a pivotal point in his development, one in which technique has truly become the handmaid of a unique dream and extraordinary compositional gift (Röhrich, 1997).

Taking our cue from Veit Erlmann's (1999:42) description of Basotho migrants' praise poetry as genres exibiting an aesthetic of autopoesis, we can describe Grové's music as constituting an intricate web of language, practice and cosmology "that speaks with an illocutory force that has the power to act on its referent and construct personal identity". Still following Erlmann closely, we may conclude that his music also enacts white South African history as a process of redemption, refusing to yield all to the current dominant social practice of "africanization" in arguing the need to return to some putatively wholesome and noble past. White history is not written out of Grové's work or present only in a unique dream inhabiting some mystical realm before time, it is the sine qua non of modern white (South) African identity. To sing about one's "place" does not mean to assume all the musical colloquialisms of that place (Erlmann, 1999:160). Grové's music serves as the powerful medium for a sustained engagement between, on the one hand, black 
South Africa and its idealized mythical past evoked by Thabo Mbeki's talk of an African renaissance, and on the other, Europe with its modern fictions about progress, nation, and individual. We are left to reflect on the oddity: that even though Rôhrich describes an Afrikaner's music as a "unique dream", she yearns for its performance by black South Africans as its only suitable celebration. As Erlmann (1999:126) writes of Janet Hodgson's critique of Ntsikana's "Great Hymn", apart from sheer condescension,

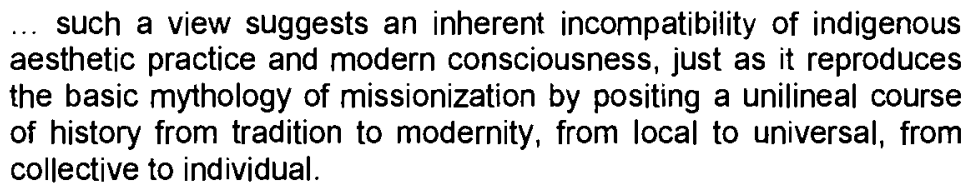

Röhrich is wrong to think that Grové's music is about representing Africa, for the composer is not composing Africa; he is using a sign that stands for Africa, that is taken for Africa and that imbues his work with "native" identity. Grove's music does not generate synthesis, xenophobia, or discernible affection for Africa. The approximate translations of the "ethnic" fall short of fashioning a national style in the way Ralph Vaughan Williams or Zoltan Kodály did with folk elements, while it is also too diluted, even tangential, to form the basis of a stylistic alternative (in the way Bartôk's music did) to the already replete stylistic palette displayed by 20 th century music.

The "African series" of Stefans Grové presents us with a form of representation that at once familiarizes and distances. The metonymical aspect of making a part stand for the whole is making Africa familiar and knowable, yet, to quote Erlmann (1999:106), the same African tune, as a generic type of "African" music, "also distances its user [Grové] from a specific locale and tradition and in so doing it is substituting representation with historical practice". In this way Grové's music partakes in play with (Afrikaner) identity that is sufficiently subversive vis-á-vis the oppositional stereotypes maintained by South African musicological discourse to transform the meaning of "African" to include Calvin ... and Jean Cocteau, that extroverted collagist whose chimerical presence laces an obsessively narcissistic discourse with welcome irony. For it was also Cocteau who said: "Since these mysteries escape me, I will pretend to be their organizer" (quoted in Griffeths, 1980:515).

\section{Bibliography}

Barthes, Roland. 1991. The responsibility of forms. Tr. Richard Howard. Berkeley \& Los Angeles : University of California Press. 
Breytenbach, Breyten. 1998. Dog heart: A travel memoir. Cape Town \& Pretoria : Human \& Rousseau

Brink, André P. 1998. Interrogating silence: New possibilities faced by South African literature. In: Attridge, Derek \& Jolly, Rosemary (eds.) Writing South Africa: Literature, apartheid, and democracy, 1970-1995. Cambridge : Cambridge University Press. p. 14-28.

ErImann, Veit. 1996. Nightsong: Performance, power, and practice in South Africa. Chicago \& London : University of Chicago Press.

Erlmann, Veit. 1999. Music, modernity and the global imagination: South Africa and the West. Chicago : Oxford University Press

Griffeths, Paul. 1980. Jean Cocteau. In: Sadie, Stanley. The new Grove dictionary of music and musicians. London: Macmillan Publishers. p. 514-515.

Grové, Stefans. 1997a. Programme notes to Obelisk concert 24 May at the Old Mutual Hall, University of South Africa.

Grové, Stefans. 1997b. Programme notes to Obelisk concert 22 November at the Old Mutual Hall, University of South Africa.

Grové, Stefans. 1998. Programme notes to Obelisk concert 23 July at the Musaion, University of Pretoria.

Nattiez, Jean-Jacques. 1990. Music and discourse: Toward a semiology of music. Tr. Carolyn Abbate. Princeton, N.J. : Princeton University Press.

Röhrich, Mary. 1997. Grové's creative urge honed by the passage of time. Business Day, April 6

Schoenberg, Arnold. 1984. Style and idea: selected writings of Arnold Schoenberg. Ed. Leonard Stein. Tr. Leo Black. Berkeley \& Los Angeles : University of California Press.

Soyinka, Wole. 1976. Myth, Literature and the African World. Cambridge : Cambridge University Press.

Watkins, Glenn. 1994. Pyramids at the louvre: Music, culture, and collage from Stravinsky to the postmodernists. Cambridge, Mass. \& London : Belknap Press of Harvard University Press.

\section{Key concepts:}

Afrikaner identity

art music

musical analysis

Sonate op Afrika-motiewe

Stefans Grové

\section{Kernbegrippe}

Afrikaner identiteit

kunsmusiek

musiekanalise

Sonate op Afrika-motiewe

Stefans Grové 